\title{
Business Intelligence Model for Sustainability of the Malaysian Rural Telecenters
}

\author{
Azizah Ahmad, Rafidah Abd Razak, Wan Rozaini Sheikh Osman, \\ Abdul Razak Bin Rahmat, Mohd Syazwan Abdullah and Abdul Bashah Mat Ali
}

International Telecommunication Union (ITU)-Universiti Utara Malaysia (UUM), Asia Pacific-Centre of Excellence (ASP CoE) For Rural ICT Development, Universiti Utara Malaysia, Malaysia

\begin{abstract}
The objective of this paper is to galvanize research on rural telecenters sustainability. The research explores the sustainability of the Malaysian rural telecenters with the support of business intelligence (BI). It is posited that BI methods and tools could play vital role in assisting telecenters implement and monitor sustainable practices. The BI information planning phase, i.e., the systematic way of defining relevant information was utilized in this research. The empirical study was conducted through interviews and observations with a range of stakeholders including ministry officers, telecenters managers and operators. A thematic model comprising of sustainability issues and challenges that arise as the roles of telecenters evolved and the relationships between these issues is developed through content analysis. This study contributes to both theory and practice by (a) the use of content analysis to discover and explicate key issues faced by rural telecenters as they aim to fill their national mission, (b) the support of the telecenters managers in enhancing participation by local communities, (c) the identification of essential capabilities for effective and socially sustainable rural telecenters, and (d) the identification of sustainability model developed which can provide a basis for future telecenter research.
\end{abstract}

Keywords: Rural telecenters, Business Intelligence, Sustainability, Malaysia.

\section{Introduction}

This paper explores how business intelligence (BI) can support the sustainability of contemporary Malaysian rural telecenters. BI methods and tools are viewed to play important roles in helping telecenters implement and monitor sustainable practices. The establishment of telecenter as multi-purpose community centre is amongst the initiatives taken by the Malaysian government to reduce digital gap in the country. One of the important issues in telecenters operations is sustainability, where the key determinant is the ability to maintain the centers' competitive advantage. This is associated with telecenter capability to run independently in terms of financial, administration, technical support as well as community acceptance and support.

After years of Malaysian Government investments in putting in place technological infrastructures and human resources that supports telecenters business operations, there came a point where the use of tools to support the decision making process at the strategic level emerges as more important than ever. A quality decision making is imperatively crucial because the outcomes of the decision indicate whether a good and sound decision has been made towards the sustainability of the telecenters. A good and quality decision is known to be significant for the organizational survival. Herein lies the importance of the area

Copyright (C) 2011 Azizah Ahmad, Rafidah Abd Razak, Wan Rozaini Sheikh Osman, Abdul Razak Bin Rahmat, Mohd Syazwan Abdullah and Abdul Bashah Mat Ali. This is an open access article distributed under the Creative Commons Attribution License unported 3.0, which permits unrestricted use, distribution, and reproduction in any medium, provided that original work is properly cited. Contact author: Dănuţ-Vasile Jemna E-mail: azie@uum.edu.my 
known as business intelligence, seen as a response to current needs in terms of access to relevant information through intensive use of information technology (Petrini \& Pozzebon, 2008). BI systems have the potential to maximize the use of information by improving the company capacity to structure a large volume of information and make it accessible, thereby creating competitive advantage, what Davenport calls "competing on analytics" (Davenport, 2005).

Moreover, BI has recently been extended to support executives and senior line-ofbusiness managers (Loftis, 2007). The strategic BI is used to support long-term corporate goals and objectives, which usually drive short-term initiatives by tactical BI applications. Common data operations behind these applications include aggregations, statistical analysis, multidimensional analysis, data mining and exploration. The business purpose includes trend and pattern discovery, development of business and behavioral models and what-if analysis; while operational BI is used to manage and optimize daily business operations, and the concepts and techniques discussed for tactical and strategic BI apply equally to operational BI (White, 2006).

Recognizing the need for an effective utilization of BI in telecenter organizations is just a first step. The real challenge is to make it an integral part of decision-making process and to help the managers in telecenters organizations obtaining and sustaining their competitive advantages. To date, little empirical research has been found in the literature on the utilization of BI for sustainability of the telecenters specifically in the Malaysian rural areas.

Therefore, this study attempts to look into these issues in terms of the following research questions:

1. What are the major issues and challenges faced by Malaysian rural telecenters in terms of sustaining their business?

2. What types of information are needed in Malaysian rural telecenters strategic business decisions in helping them achieve and sustain their competitive advantage?

3. How can BI help Malaysian rural telecenters sustain their competitive advantage?

The main aim of the study is to provide a BI model for sustainability of the Malaysian rural telecenters for supporting the managers in their decision making tasks. $\mathrm{BI}$ in this case should provide managers with the appropriate actionable knowledge that enables telecenters managers to make informed decisions regarding the sustainability of the telecenters.

The remainder of the paper is structured as follows: The next section presents a review of literature around the two main themes of Malaysian telecenter and BI as well as the relationship between these themes and then proceeds by Section 2 which explains the qualitative study method employed by the study. Section 3 shows the result of the study and the BI model for sustainability of the Malaysian rural telecenters, and finally Section 4 contains the conclusion and future study.

\section{Literature Review}

This section provides the review on the following themes: (1) Malaysian telecenters, (2) Business intelligence, and (3) BI and Sustainability.

\section{Malaysian Telecenters}

In Malaysia, telecenters initial objective is to reduce digital gap in the country. Digital divide can be described as disparities between and within societies in the use of digital technologies or a situation whereby part of a community is deprived of the opportunity to gain access to ICT infrastructure facilities (Zulkhairi, 2007).

The Malaysian Economic Planning Unit views digital divide is as giving values towards the benefits of development generated through ICT (Yogeesvaran, 2007). 
The telecenters offer a broad range of communication services related to the needs of the community with the idea of a community sharing computer technologies. In Malaysia, more than 2,000 telecenters of various types were initiated either by government departments or private organizations. These centers such as Rural Internet Center, Medan Info Desa, Community Broadband Center and Rural Broadband Library (Norizan \& Jalaluddin, 2008) have their own objectives, aims, basic infrastructures, business activities, hierarchy structure and financial supports.

A range of important issues is linked to the operation and success of telecenters. These include: sustainability, community relevance, government policy, information and communication technology (ICT), research, community partnerships and participation, telecenter objectives and business planning (Roman \& Colle, 2002). Often mentioned but largely undeveloped is the sustainability associated with telecenter, an issue that relates to all of the issues mentioned. Wrong focus often leads to failure. At the same time, it is important to achieve balance between financial and social sustainability. Telecenters receive certain amounts of money from several sources to assist them in sustaining operations and services. The majority of telecenters are currently operating under tight cash budget and financial support is critical in order for the centers to continue giving services to communities (Huda, Azman \& Zulkhairi, 2010). The Malaysian government plans to reduce the funding of the government-operated telecenters soon; therefore, there is a need to formulate new strategies to self-sustain the telecenters operation.

Telecenter sustainability means more than financial sustainability. Currently the telecenters face the question of how they can generate income yet serve those in the community who cannot afford to pay for "public goods" kinds of services. Colle (2000) reported that some centers use the income from user fees and other income services to make public goods affordable or free. Harris (2007) argues that it is a mistake to write off telecenters that are able to induce locally relevant development but do not generate sufficient revenue to cover their costs.

\section{Business Intelligence}

In the current competitive environment, business intelligent has a profound impact on a quality decision making. Keyes (2006) refers to BI as a set of methodologies and technologies for gathering, storing, analyzing, and providing access to data to help users make better business decisions. Thus, BI can generally be referred to as a process of turning data into information and then into knowledge that can be use for good decision making (Liebowitz, 2005; Golfarelli, 2004; Kahaner, 1996). Bernstein et al. (2001) defined BI in a broader term as the utilization of highlevel software intelligence for business applications. Specifically, they defined BI as a collection of cutting-edge technologies that help to make systems more intelligent. Chung et al. (2002), Liebowitz (2005), Davies (2002) and Chung et al. (2005) put forward the idea of BI enables organizations to understand their internal and external environment through systematic acquisition, collation, analysis, interpretation and exploitation of information in the business domains.

BI as a term started more than 35 years ago, as initial versions of analytical software packages appeared on the market in the 1970s. In the 1990s, three technological improvements brought about a revolution in analytical applications scenarios, accounting for the emergence of business intelligence (BI) systems: data warehouse technologies (Inmon, 1996; Kimball, 2000), ETL tools (extraction, transformation and loading) and powerful end-user analytical software with OLAP capabilities (online analytical processing) (Body et al., 2002). Furthermore, the impact of the internet is far from negligible: current versions of analytical products are web-based and, through Internet or intranet connections, users can investigate and analyze data from home, while traveling or from any other location (Carlsson \& Turban, 2002). Today, terms like DSS and EIS have virtually 
disappeared, and BI is the accepted term for analytical and strategic information systems, including an array of applications classified under three broad headings: analysis (data mining and OLAP), monitoring (dashboards, scorecards and alert systems) and reporting.

Almost all definitions found in the literatures share the same focus, even though definitions have been made from two broad perspectives of managerial and technical (Casado, 2004; Petrini \& Pozzebon, 2009; Niu, Lu \& Zhang, 2009). The managerial approach sees $\mathrm{BI}$ as a process that gathers data from inside and outside of organizations and integrates them in order to generate information relevant to decision-making process. Whereas the technical approach presents $\mathrm{BI}$ as a set of tools that support the process. Despite the differences in approach, they all include the idea of analysis of data and information. The main idea of BI is to aid in controlling the vast stocks and flow of business information around and within the organization by first identifying and then processing the information into condensed and useful managerial knowledge and intelligence.

Table 1: Types of BI

\begin{tabular}{|l|l|c|}
\hline \multicolumn{1}{|c|}{ Types of BI } & \multicolumn{1}{|c|}{ Definition } & \multicolumn{1}{c|}{ Author(s) } \\
\hline Strategic & $\begin{array}{l}\text { Developed to support long-term corporate goals and } \\
\text { objectives and applications include aggregations, } \\
\text { statistical analysis, multidimensional analysis, data } \\
\text { mining and exploration. }\end{array}$ & Loftis, 2007 \\
\hline Tactical & $\begin{array}{l}\text { Developed for business analysts and experts whose } \\
\text { daily jobs involve accessing and analyzing data and } \\
\text { were targeted at making short-term business } \\
\text { decisions. }\end{array}$ & $\begin{array}{l}\text { Imhoff \& } \\
\text { Pettit, 2004 }\end{array}$ \\
\hline Operational & $\begin{array}{l}\text { Used to manage and optimize daily business } \\
\text { operations and evolved to meet the need to respond } \\
\text { to specific events that happen in the operational } \\
\text { world. }\end{array}$ & 2006 \\
\hline
\end{tabular}

Most researchers and practitioners categorize $\mathrm{BI}$ applications into three types: (1) Strategic BI, (2) Tactical BI and (3) Operational BI (Loftis, 2007; White, 2006; Imhoff \& Pettit, 2004; Sullivan, 1996). The only real difference between these three types of BI application lies in the granularity of the data being analyzed and the frequency, at which it is being captured, analyzed and reported as shown in Table 1.

\section{BI and Sustainability}

BI method is claimed to involve methodologies focusing on identification of strategic information which needs to be integrated into data warehouses and BI applications (Miranda, 2004). The BI literature displays a lack of clear frameworks that could serve as guides to such an important phase: the definition of user requirements and information needs. The literature on $\mathrm{BI}$ is short on methodological approaches to information planning. Research by Taydi (2006) shows that most methodologies applied in BI projects are proposed by vendors and consulting firms, and that those methodologies are not examined, validated or tested by BI academic research.

Faced with this absence of conceptual frameworks in BI literature, the study reviewed literature on related area of data warehousing. In the data warehousing literature, one finds a huge number of studies based on two authors, Inmon (1996) and Kimball (2000), who are directly concerned with defining the structure and content of a data warehouse. However, both Inmon and Kimball provide few guidelines regarding definition of corporate performance indicators, which is the heart of a BI system from a corporate level perspective. 
This research uses the information planning method which focuses on understanding the internal and external environment surrounding the telecenters as the conceptual foundation. The decision to use the method is grounded on the reason that business intelligence planning phase, which focuses on identifying strategic information can be used to help the telecenters organizations to identify their strategic information needed in sustaining their operations. The study attempts to probe deeper into the internal and external environment of these telecenters in order to understand the required strategic information. There is also some gap in the literature on BI and telecenters sustainability that can be addressed in this study.

\section{Study Method}

The paradigm of the research is qualitative, in which field study is used as a research method. The field study is appropriate in this context since the real organization is explored. A convenient non-random method is employed in choosing the samples for the data collection. Semistructured interview is then performed in getting the required data. The details of our field study are presented below.

\section{Sample}

A convenient non-random type of sampling is used to select 18 managers and operators who are involved in the management and operation of rural telecenters in Malaysia. According to Zikmund (2000), convenience sampling is always undertaken in business research. The main criterion of sample selection is based on their level of involvement in decision making and their active involvement in the operations of the telecenters. All of the participants are selected based on personal contacts with permissions from their respective organizations and their responses are on voluntary basis. Table 2 below provides a brief overview of the participants in various telecenter-related organizations including ministry and rural telecenters who take part in the field study.

Table 2: Demographics of the Participants

\begin{tabular}{|c|l|l|l|}
\hline Participant & Type of Organization/Telecenter & Position & Education \\
\hline 1 & $\begin{array}{l}\text { Ministry of Information, Communication and } \\
\text { Multimedia }\end{array}$ & Director & Master's Degree \\
\hline 2 & $\begin{array}{l}\text { Economic Planning Unit, Prime Minister's } \\
\text { Department }\end{array}$ & Director & Master's Degree \\
\hline 3 & Ministry of Rural and Regional Development & Assistant Director & Bachelor's Degree \\
\hline 4 & Community Broadband Center & Director & Master's Degree \\
\hline 5 & Malaysian Communications and Multimedia & Manager & Bachelor's Degree \\
\hline 6 & Rummission & Manager & \\
\hline 7 & Rural Internet Center & Assistant Manager & Diploma \\
\hline 8 & Rural Internet Center & Manager & Bachelor's Degree \\
\hline 9 & Rural Internet Center & Manager & Diploma \\
\hline 10 & Rural Internet Center & Manager & Diploma \\
\hline 11 & Rural Internet Center & Manager & Bachelor's Degree \\
\hline 12 & Rural Internet Center & Operator & Diploma \\
\hline 13 & Rural Internet Center & Manager & Bachelor's Degree \\
\hline 14 & Community Broadband Center & Assistant Manager & Diploma \\
\hline 15 & Community Broadband Center & Manager & Bachelor's Degree \\
\hline 16 & Rural Internet Center & Manager & Bachelor's Degree \\
\hline 17 & Rural Internet Center & Manager & Bachelor's Degree \\
\hline 18 & Rural Internet Center & Manager & Diploma \\
\hline
\end{tabular}




\section{Data Collection}

The semi-structured interview questions have focused on the following areas of information needed in the study:

- Please give some overview of Malaysian rural telecenters

- What is the motivation for establishing the telecenters?

- In your opinion, what are the issues and challenges faced by telecenters currently?

- In your opinion, do we still need telecenters now as people now own computers at home?

- What do you think are some of the main factors that contribute to telecenters' sustainability?

- What is the source of income of your telecenters?

- What are the main problems that you face in managing the telecenters?

- What do you think in terms of knowledge or information needed for decision making in regard to telecenters sustainability?
- Do you think that your telecenter can be sustainable?

The interviews are scheduled as per convenience of the interviewees to ensure less disruptions and interruptions in their working schedule. Prior to an interview session, a participant is contacted by telephone to provide an idea of the interview process and some brief understandings of the study. The duration of a one-to-one interview session takes about 1 to 2 hours to complete. Fruitful discussions were observed during the sessions where the interviewer managed to tap some of the information that was not pre-defined in the questions. This may be due to the fact that most of the participants are aware of the subject matter and they are quite involved in telecenters management and operations.

\section{Data Analysis}

Content analysis was chosen to analyze the data because of the qualitative field study is exploratory in nature, rather than confirmatory. There are more than 100 pages of verbatim transcripts from microaudio and notes to be analyzed despite the fact that only 18 participants are involved in the interviews. Content analysis is carried out in two phases as detailed out in Figure 1 below. 


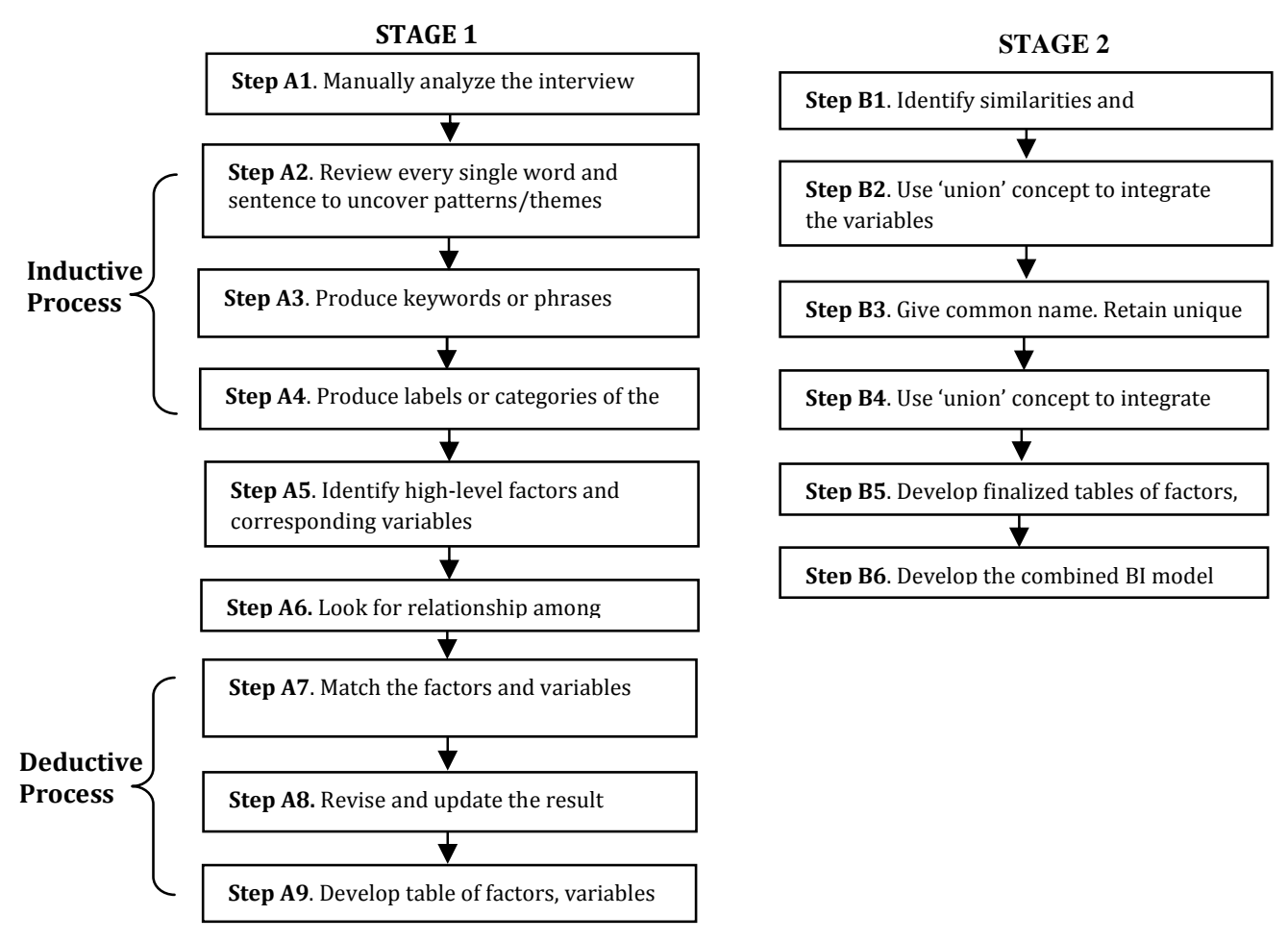

Figure 1: Content Analysis Process

Phase one involves analysis of an individual script, while phase two deals with integrating these individual scripts (Miles \& Huberman 1994; Berg 2004; Xu 2005). Analysis is conducted manually because of the nature of a simple language used by Malaysian participants. The researcher has to carefully interpret the meaning of every word and sentence uttered by participants. A combination of inductive and deductive approaches is then performed to categorize the factors and variables.

All the interview transcripts are first carefully analyzed manually (Step A1). An inductive process is first performed on the transcripts, where every single word and sentence is reviewed to uncover key patterns or themes (Step A2). Keywords or phrases are produced at this stage in order to be used later (Step A3). The key words or phrases are given labels or categories (Step A4). High-level factors and corresponding variables are identified. The relationship between factors from each script is identified next (Step A5). A deductive process is performed here where the identified factors are matched with the ones found in the literature previously (Step A6). These factors are revised and updated accordingly without scarifying any factors and variables obtained from the interviews (Step A7). Table of factors and variables is finally developed for each interview (Step A9).

The main aim of the second phase of the content analysis is to develop a finalized BI model based on the factors, variables and links that have been identified in the previous phase. The best way to do so is to integrate all the information gathered so far into one single entity. As shown in Step B1, the similarities and differences of variables under each factor are identified. A mathematical 'union' concept is used at Step B2 in integrating the similar variables. The new combined variable is given a new name and unique variables are retained (Step B3). The same 'union' concept is used to integrate the links among the factors (Step B4). Then, Step B5 developed the final table of factors and variables. Finally, the new combined BI model is developed. 


\section{Results}

Table 2 presents the demographics information on the participants involved in the study. A number of 18 decision makers and managers in Malaysian rural telecenters are involved in the study. The participants who took part in the study range from the director of ministry who was initially responsible for the setting-up of the telecenters initiatives to the operators who are responsible for the daily operations of the telecenters. They willingly took part in the study and it should be noted that all of them had some level of decision-making as part of their responsibilities. Additionally, the levels of involvement in telecenters management and operations among them were fairly high. As a result, the majority of them were aware of the issues involved with sustaining telecenters competitiveness especially in the rural areas, through their working experience. All of the participants were also aware of the importance of acquiring knowledge in decision-making process and they were to certain extent contributing to the process of policymaking for telecenters.

\section{Factors and Variables of Sustainability of the Malaysian Rural Telecenters}

From the content analysis, 7 factors and 25 different variables of sustainability of the Malaysian rural telecenters are produced as provided in Table 3 below.

\section{Table 3: Factors and Variables of Sustainability of the Malaysian Rural Telecenters}

\begin{tabular}{|c|c|c|c|c|c|c|c|c|c|c|c|c|c|c|c|c|c|c|c|}
\hline Factors/Items & 1 & 2 & 3 & 4 & 4 & 5 & 6 & 7 & 8 & 9 & $\begin{array}{l}1 \\
0\end{array}$ & $\begin{array}{l}1 \\
1\end{array}$ & $\begin{array}{l}1 \\
2\end{array}$ & $\begin{array}{l}1 \\
3\end{array}$ & $\begin{array}{l}1 \\
4\end{array}$ & $\begin{array}{l}1 \\
5\end{array}$ & $\begin{array}{l}1 \\
6\end{array}$ & $\begin{array}{l}1 \\
7\end{array}$ & $\begin{array}{l}1 \\
8\end{array}$ \\
\hline $\begin{array}{l}\text { LOCAL CHAMPIONS } \\
\text { - Commitment } \\
\text { - Creative } \\
\text { - Independence } \\
\text { - Willingness to learn continuously } \\
\text { - Business-oriented }\end{array}$ & $\begin{array}{l}\text { / } \\
\text { / } \\
\text { / } \\
\text { / }\end{array}$ & $\begin{array}{l}\text { / } \\
\text { / } \\
\text { / } \\
\text { / }\end{array}$ & $\begin{array}{l}1 \\
2 \\
/ \\
/ \\
/\end{array}$ & $\begin{array}{l}\text { l } \\
\text { / } \\
\text { / } \\
\text { / }\end{array}$ & $\begin{array}{l}\text { / } \\
\text { / } \\
\text { / } \\
\text { / }\end{array}$ & $\begin{array}{l}1 \\
1 \\
1 \\
1\end{array}$ & $\begin{array}{l}\text { / } \\
\text { / } \\
\text { / } \\
\text { / }\end{array}$ & $\begin{array}{l}1 \\
1 \\
1 \\
1\end{array}$ & $\begin{array}{l}1 \\
2 \\
2 \\
/ \\
/\end{array}$ & $\begin{array}{l}1 \\
2 \\
2 \\
2 \\
1\end{array}$ & $\begin{array}{l}\text { l } \\
\text { / } \\
\text { / } \\
\text { / }\end{array}$ & $\begin{array}{l}/ \\
/ \\
/ \\
/ \\
/\end{array}$ & $\begin{array}{l}\text { I } \\
\text { / } \\
\text { / }\end{array}$ & $\begin{array}{l}1 \\
1 \\
1\end{array}$ & $\begin{array}{l}1 \\
2 \\
2 \\
1 \\
1\end{array}$ & $\begin{array}{l}1 \\
2 \\
2 \\
1 \\
1\end{array}$ & $\begin{array}{l}\text { I } \\
\text { I }\end{array}$ & $\begin{array}{l}1 \\
1 \\
1 \\
1 \\
1\end{array}$ & $\begin{array}{l}\text { / } \\
\text { / } \\
\text { ' } \\
\text { / }\end{array}$ \\
\hline $\begin{array}{l}\text { GOVERNANCE } \\
\text { - Identify champions } \\
\text { - Policy enforcement } \\
\text { - Strong financial support }\end{array}$ & I & $\begin{array}{l}\text { I } \\
\text { / }\end{array}$ & $\begin{array}{l}\text { I } \\
\text { / }\end{array}$ & I & $\begin{array}{l}\text { / } \\
\text { / }\end{array}$ & $\begin{array}{l}\text { I } \\
\text { / }\end{array}$ & I & $\begin{array}{l}\text { I } \\
\text { / }\end{array}$ & I & $\begin{array}{l}1 \\
\text { I } \\
\text { I }\end{array}$ & I & / & I & $\begin{array}{l}1 \\
1 \\
1\end{array}$ & $\begin{array}{l}1 \\
1 \\
1\end{array}$ & $\begin{array}{l}1 \\
1 \\
1\end{array}$ & I & $\begin{array}{l}1 \\
1 \\
1\end{array}$ & $\begin{array}{l}\text { I } \\
\text { / }\end{array}$ \\
\hline $\begin{array}{l}\text { MULTIPLE COMMITTEES } \\
\text { - Socially-oriented } \\
\text { - Business-oriented } \\
\text { - Technically-oriented }\end{array}$ & $\begin{array}{l}\text { I } \\
\text { / }\end{array}$ & $\begin{array}{l}\text { / } \\
\text { / }\end{array}$ & $\begin{array}{l}\text { l } \\
\text { / }\end{array}$ & $\begin{array}{l}\text { / } \\
\text { / }\end{array}$ & $\begin{array}{l}1 \\
1 \\
1\end{array}$ & $\begin{array}{l}1 \\
1 \\
1\end{array}$ & $\begin{array}{l}1 \\
1 \\
1\end{array}$ & $\begin{array}{l}1 \\
1 \\
1\end{array}$ & $\begin{array}{l}\text { I } \\
\text { / } \\
/\end{array}$ & $\begin{array}{l}\text { I } \\
\text { I } \\
\text { I }\end{array}$ & $\begin{array}{l}\text { I } \\
\text { I } \\
\text { I }\end{array}$ & $\begin{array}{l}/ \\
/ \\
/\end{array}$ & $\begin{array}{l}1 \\
1 \\
1\end{array}$ & $\begin{array}{l}1 \\
1 \\
1\end{array}$ & $\begin{array}{l}1 \\
1 \\
1\end{array}$ & $\begin{array}{l}1 \\
1 \\
1\end{array}$ & $\begin{array}{l}\text { I } \\
\text { I }\end{array}$ & $\begin{array}{l}1 \\
1 \\
1\end{array}$ & $\begin{array}{l}\text { I } \\
\text { / }\end{array}$ \\
\hline $\begin{array}{l}\text { SMART PARTNERSHIP } \\
\text { - Telecenter } 2.0 \\
\text { - Partner with government and non- } \\
\text { government } \\
\text { - Entrepreneurially-oriented }\end{array}$ & / & & / & & & & & & & & & & & & & & & & \\
\hline $\begin{array}{l}\text { LOCAL COMMUNITY PARTICIPATION } \\
\text { - Active community involvement } \\
\text { - Committed }\end{array}$ & / & I & I & I & 1 & $\begin{array}{l}1 \\
1\end{array}$ & $\begin{array}{l}1 \\
1\end{array}$ & $\begin{array}{l}1 \\
1\end{array}$ & $\begin{array}{l}1 \\
1\end{array}$ & $\begin{array}{l}1 \\
1\end{array}$ & I & / & $\begin{array}{l}1 \\
1\end{array}$ & $\begin{array}{l}1 \\
1\end{array}$ & $\begin{array}{l}1 \\
/\end{array}$ & l & $\begin{array}{l}1 \\
1\end{array}$ & $\begin{array}{l}1 \\
1\end{array}$ & I \\
\hline $\begin{array}{l}\text { LOCATION } \\
\text { - Suitable location - close to public } \\
\text { places such as mosque, post office and } \\
\text { market } \\
\text { - Comfortable - air-conditioned and cafe } \\
\text { - Multi-purpose/functions place } \\
\text { - Can support multi-ethnic community }\end{array}$ & $\begin{array}{l}\text { / } \\
\text { / } \\
\end{array}$ & / & $\begin{array}{l}\text { / } \\
\text { / } \\
/\end{array}$ & $\begin{array}{l}1 \\
1 \\
1\end{array}$ & $\begin{array}{l}1 \\
/ \\
/\end{array}$ & $\frac{1}{2}$ & $\begin{array}{l}1 \\
/ \\
/\end{array}$ & $\begin{array}{l}1 \\
/ \\
/\end{array}$ & $\begin{array}{l}/ \\
/ \\
/\end{array}$ & $\begin{array}{l}/ \\
/ \\
/\end{array}$ & $\begin{array}{l}\text { l } \\
\text { / } \\
\text { l }\end{array}$ & $\begin{array}{l}1 \\
/ \\
/\end{array}$ & $\begin{array}{l}/ \\
/ \\
/\end{array}$ & $\begin{array}{l}\text { l } \\
\text { / } \\
\text { l }\end{array}$ & $\begin{array}{l}2 \\
2 \\
1\end{array}$ & $\begin{array}{l}1 \\
2 \\
/\end{array}$ & $\begin{array}{l}2 \\
2 \\
/\end{array}$ & $\begin{array}{l}1 \\
2 \\
1\end{array}$ & $\begin{array}{l}\text { / } \\
\text { / }\end{array}$ \\
\hline $\begin{array}{l}\text { SERVICES } \\
\text { - Basic and advance ICT training to cater } \\
\text { for all levels of community } \\
\text { - Provide comprehensive services to } \\
\text { cater for rural needs } \\
\text { - Should be affordable to all } \\
\text { - Better services such as broadband } \\
\text { speed } \\
\text { - Operations time should be flexible }\end{array}$ & $\begin{array}{l}\text { / } \\
\text { / }\end{array}$ & $\begin{array}{l}\text { / } \\
\text { / }\end{array}$ & I & / & I & I & I & I & I & I & I & $\begin{array}{l}/ \\
/\end{array}$ & I & I & I & I & $\begin{array}{l}\text { I } \\
\text { I }\end{array}$ & $\begin{array}{l}\text { / } \\
\text { / } \\
/\end{array}$ & 1 \\
\hline
\end{tabular}


Different participants have mentioned either similar or different variables during the interview sessions. Factors which are considered primary are: (1) Telecenter Champion, (2) Governance, (3) SmartPartnership Strategy, (4) Community Participation, (5) Services, (6) Location, and (7) Multiple Committees. It is interesting to note that out of 25 different variables; 18 variables are mentioned by all 18 participants. These variables are commitment, creative, independence, policy enforcement strong financial support, socialyl-oriented, business-oriented, technically-oriented, active participation, committed community, suitable location, comfortable, training that cater for all, comprehensive services, affordable, good services and flexible operations hours and these variables are called major significant (not in statistical sense) variables.

The responses from the participants confirm the factors of internal and external factors on telecenter's sustainability. For the internal resources factors, suitable locations and good services receive majority of responses from the participants. Whereas external factors of multiple committees and community participation receive majority responses. However, there is limited support for the influence of smart-partnership program although this factor is identified as important factor in the telecenter's management in general. Only two participants, a director and a manager from ministry, mention this factor.

There are also very strong supports from amongst the participants for the factor of telecenter's governance. In order for any telecenter organizations to sustain in the current global environment, strong governance within the organizations is vital. These organizations still very much in need of government support in terms of policy enforcement as well as financial.
These supports are considered 'can't live without' by some of the managers in managing their telecenters.

Telecenter champion is one of the most significant variables affecting sustainability of the telecenters in rural Malaysia. The champion who posses good management characteristics such as, being committed, creative and independent, is needed in telecenters management team. $\mathrm{He} / \mathrm{she}$ is expected to drive the surrounding community in terms of utilizations of the ICT services offered by the telecenter. The champion is also urged to acquire the sense of business competition culture in order to stay ahead of the competition.

\section{BI Model for Sustainability of the Malaysian Rural Telecenter}

Figure 2 presents the model of $\mathrm{BI}$ for sustainability of the Malaysian rural telecenters. The model is unique in the sense that it has been developed based on the data obtained from 18 interviews in different telecenters organizations. Although no formal propositions are developed in this paper, the model can still be taken as a research model for further investigation. A causal modeling approach such as structural equation modeling (SEM) can be undertaken to test the model.

The combined model has 7 factors and 25 variables. It is observed that the basic BI planning phase of identifying internal and external factors, which are obtained from the literature, apply quite effectively in the telecenters sustainability. The factors of Telecenter Champion, Governance, Suitable Location, and Effective Services fall under telecenter's internal resources. Factors of Smart-Partnership Program, Local Community Participation and Multiple Committees are considered external factors in determining sustainability of the telecenters. 


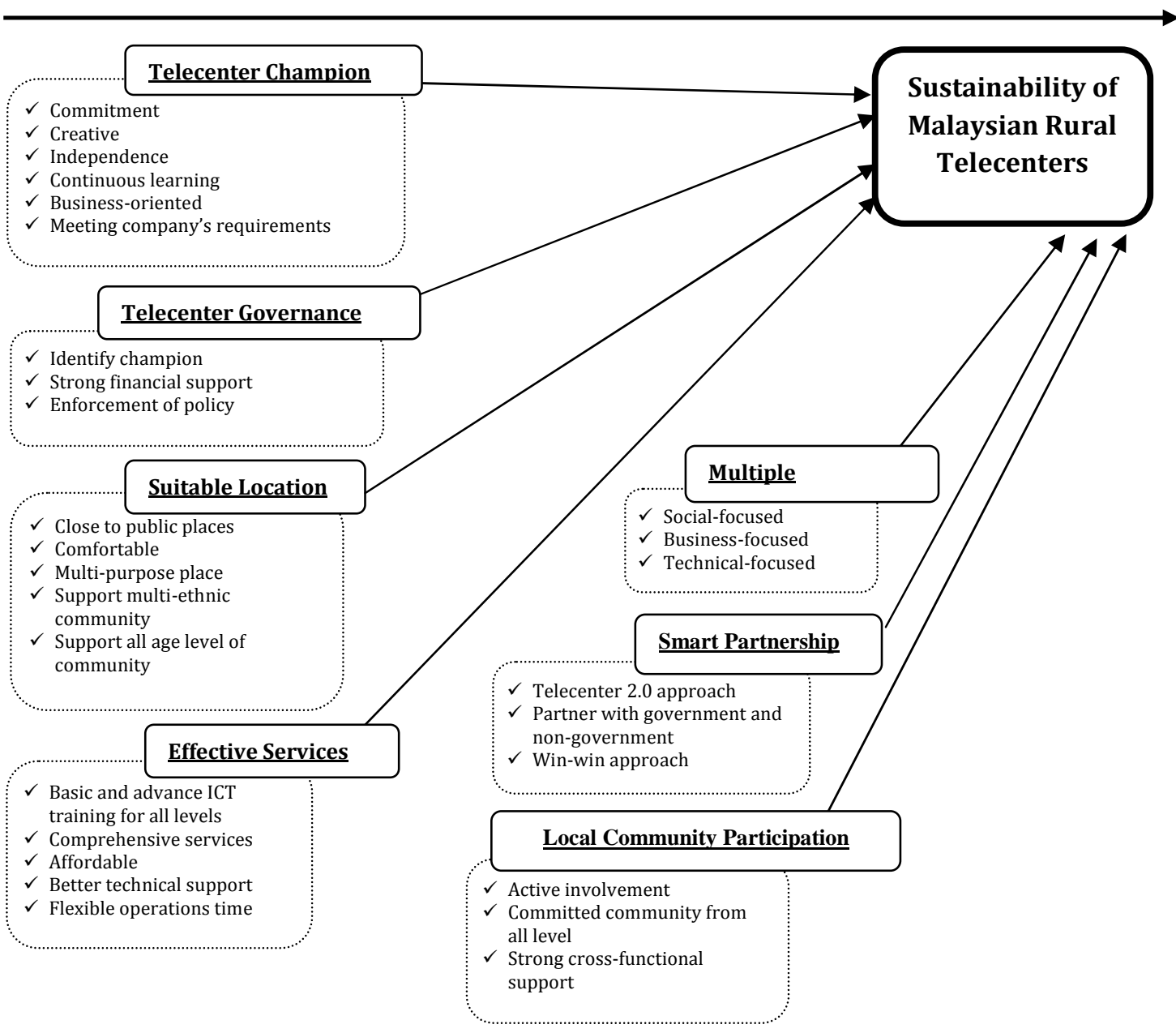

Figure 2: BI Model for Sustainability of the Malaysian Rural Telecenters

Telecenters organizations which are currently operating their business in rural areas, can consider these factors and variables as criteria to improve and sustain their business. Organizations which are planning to start their telecenter business in rural areas can also consider these variables as criteria of successful implementation. However, these criteria may not be applicable to all telecenters organizations as careful analysis is first needed to select the appropriate criteria for the organizations.

\section{Conclusion and Future Study}

This paper has focused on outlining the importance of utilizing business intelligence approach in the sustainability of the Malaysian telecenters. A qualitative approach is employed where telecenter in the rural areas in Malaysia took part. Semistructured interviews were conducted with selected 18 decision-makers and managers giving their views on various issues concerning issues and challenges that lead to the telecenter sustainability. The interviews were transcribed and the contents were analyzed thoroughly using content analysis method, which resulted in 7 factors and 25 different variables. The findings from the literature combined with the field study findings form the final BI for sustainability of Malaysian rural telecenters. The model represented a comprehensive set of determinants that 
are believed to influence the telecenter sustainability. It is perceived that telecenters organizations can be sustained by successfully adopting some of the internal and external factors within their organizations. The model focuses on the importance of commitment and support of the communities. The model also reveals that the role of other community entities in forming so-called smart-partnership program is crucial in ensuring the telecenters sustainability. Consequently, there must be strong governance in terms of providing necessary physical and human resource infrastructure in the telecenters in order to face the environmental changes. The researchers believe this to be a valuable insight that can make the sustainability of the Malaysian telecenters a reality.

This study contributes to the literature in the following ways. The model will suggest the types of variables that need to be included in future empirical tests of the relationship between internal resources as well as external ones surrounding telecenters and sustainable competitive advantage. Consequently, the model extends understanding of what is becoming increasingly important issue in telecenter management, especially the relationship between BI planning phase and sustainable competitive advantage. From the practical point of view, it is expected that a better understanding of determinant factors in sustaining telecenters will be realized in the context of Malaysian rural environment. Business practitioners especially telecenter policy makers and managers can also use the model to refine their thinking about telecenter management and their strategic resources. The model will suggest the types of investments that are most likely to be the sources of sustained competitive advantage.

Due to the exploratory nature of this study, future research on larger samples would help in gaining better perspective on business intelligence practices and address the questions of the sustainability within the telecenters. It is also suggested that the proposed BI model for the Malaysia telecenters sustainability be validated using acceptable methods such as structural equations modeling (SEM) techniques. The researchers' immediate future plan is to study the model further using SEM. This part of the research will use a quantitative approach, which will test a number of hypotheses and the model itself.

\section{References}

Bernstein, A., Gorsof, B. \& Provost, F. (2001). "Business Intelligence: the Next Frontier for Information Systems Research? Panel description," Proceedings of the Workshop on Information Technologies and Systems (WITS'01), New Orleans, LA, USA, Dec. 15-16, 2001.

Chung, W., Chen, H. \& Nunamaker Jr., J. F (2003). "Business Intelligence Explorer: a Knowledge Map Framework for Discovering Business Intelligence on the Web," Proceedings of the 36th Hawaii International Conference on System Sciences (HICSS'03), Hawaii, USA.

Chung, W., Chen, H. \& Nunamaker Jr., J. F (2005). "A Visual Framework for Knowledge Discovery on the Web: an Empirical Study of Business Intelligence Exploration," Journal of Management Information Systems, Spring 2005, 21(4), 57-84.

Colle, R. (2000). "Communication Shops and Telecenters in Developing Nations," in Gurstein, M. (ed), Community Informatics: Enabling Communities with Information and Communications Technologies, Idea Group Press, Hershey, PA.

Davenport, T. H., 2005. Competing on Analytics. Harvard Business Review.

Golfarelli, M. (2005). "New Trends in Business Intelligence," Invited paper. In Proceedings 1st International Symposium on Business Intelligent Systems (BIS'05), Opatija, Croatia. 
Harris, R. (2007). "Telecentre Sustainability- Financing ICTs for the poor," APDIP e-Note 15 / 2007. [Online]Available:

http://www.apdip.net/apdipenote/15.pdf (March 18, 2010).

Ibrahim, H., Yasin, A. \& Dahalin, Z. M. (2010). "Financial Sustainability Issues in Malaysia's Telecentres," Computer and Information Science, Vol. 3, No. 2; pp 235240.

Kahaner, L. (1996a). 'Competitive Intelligence: How to Gather, Analyze and Use Information to Move your Business to the Top,' Simon \& Schuster: New York, USA.

Keyes, J. (2006). "Knowledge Management, Business Intelligence, and Content Management: the IT Practitioner's Guide," Auerbach Publications: Boca Raton, USA.

King, M. K. (1997). "We should, but don't" Paradox: Exploring User Acceptance of a Business Intelligence System," Doctoral of Business Administration (DBA) Thesis, Graduate School of Business Administration, Harvard University.

Liebowitz, J. (2005). “Business Intelligence Cannot Exist Without Knowledge Management," Available at http:/www.businessintelligence.com.

Loftis, L. (2007). 'What's in the Name? Strategic, Tactical and Operational BI,' DM Review, New York, Sep 1 2007, Vol. 17, Iss. 9. pp. 32.

Petrini, M. \& Pozzebon, M. (2004). "What role is "Business Intelligence" playing in developing countries? A picture of Brazilian companies," In: Rahman, Hakikur (Eds.), Data Mining Applications for Empowering Knowledge Societies, IGI Global, pp. 237-257 (Chapter XIII).

Razak, N. A. \& Malek, J. A. (2008). “Bridging digital divide in Malaysia: Cyber learning for the marginalized community," Distance Learning and the Internet Conference 2008. 19-22 November, Waseda University, Tokyo, Japan.
White, C. (2006). 'A Process-Centric Approach to Business Intelligence,' DM Review, Vol. 16, Iss. 12, pp. 14-18.

Yogeesvaran, K. (2007). “National Strategic Framework for Bridging the Digital Divide and the Need for Upgrading and Expanding ICT Infrastructure," Presented at MyBroadband 2007 Conference and Exhibition, MATRADE Exhibition Convention Centre, Kuala Lumpur, 10-12 September 2007.

Zikmund, W. G. (2000). Exploring Marketing Research, 7th Edition, Fort Worth, USA: the Dryden Press.

Zulkhairi, M. D. (2007). 'Initiatives for Reducing Digital Gap, in a workshops series of Community Services and Knowledge Center,' Ministry of Energy, Water and Communication, Malaysia. 